\title{
Curriculum Teaching Process Design and Research Based on TOPCARES-CDIO
}

\author{
Chong Zhang ${ }^{1, \mathrm{a}, *}$ and Baocai Zhong ${ }^{1, \mathrm{~b}}$
}

\author{
${ }^{I}$ Department of Information and Software Engineering, Chengdu Neusoft University, Chengdu, Sichuan, China

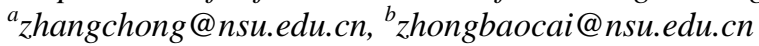 \\ *corresponding author
}

\begin{abstract}
A new curriculum teaching process design method with competence training as the core is proposed based on the international advanced TOPCARES-CDIO engineering education idea. Taking the curriculum Web Application Development as an example, this paper describes the whole process from the determination of curriculum objectives to the design of curriculum teaching methods, and finally to the assessment of the curriculum. This method guides activities closely around T-C index, and achieves good results in practical application.
\end{abstract}

Keywords: CDIO, teaching method, curriculum design, competence indicator

\section{INTRODUCTION}

CDIO engineering education model is the latest achievement of international engineering education reform in recent years. CDIO stands for Conceive, Design, Implement and Operate. It takes the life cycle from product development to product operation as the carrier to enable students to learn engineering in an active, practical and interdisciplinary way. The CDIO training outline divides the abilities of engineering graduates into four levels: basic engineering knowledge, personal ability, interpersonal team ability and engineering system ability. The outline calls for comprehensive training to enable students to achieve their intended goals at these four levels. Based on the concept of "Education Creates Student Value" and CDIO, Dalian Neusoft Information Institute creatively constructs the "Eight Competences" index system of TOPCARES-CDIO (T-C) with Neusoft's characteristics, namely: Technical Knowledge and Reasoning, Open Mind and Innovation, Personal and Professional Skills, Communication and Teamwork, Attitude and Manner, Responsibility, Ethical Values, Social Value Created by Application Practice. Under these eight first-level competence indicators, 34 second-level indicators and 126 third-level indicators are constructed, thus constituting a complete major competence index system. This paper is based on the T-C competence index of the course Web Application Development as an example, and puts forward a complete set of curriculum design and assessment program.

\section{Course Objective Determination}

T-C competence indicators of courses are selected from major T-C competence indicators, which are suitable for centralized cultivation in a certain course. Firstly, we analyze the T-C indicators of Software Engineering Major (which are obtained through market research of software development industry and original T-C indicators system), and select the indicators that need to be trained in the course of Web Application Development, thus forming the T-C indicators set of the course, as shown in the table below.

\begin{tabular}{|c|c|c|c|}
\hline $\begin{array}{c}\text { T-C } \\
\text { Indicators } \\
\text { Level } 1\end{array}$ & $\begin{array}{l}\text { T-C Indicators } \\
\text { Level } 2\end{array}$ & T-C Indicators Level 3 & Capability Indicators Description \\
\hline $\begin{array}{l}1 \text { Technical } \\
\text { Knowledge } \\
\text { and Reasoning }\end{array}$ & $\begin{array}{l}\text { 1.3 Professional } \\
\text { Knowledge }\end{array}$ & $\begin{array}{l}\text { 1.3.1 Professional } \\
\text { Knowledge }\end{array}$ & $\begin{array}{l}\text { 1、 Installation, Configuration and Web Publishing of Web } \\
\text { Server } \\
\text { 2、 The basics of HTML, CSS, JavaScript, etc. } \\
\text { 3、 JSP } \\
\text { 4、 Servlet } \\
\text { 5、 JDBC, Filter, Listener }\end{array}$ \\
\hline \multirow{2}{*}{$\begin{array}{l}2 \text { Open } \\
\text { Thinking and } \\
\text { Innovation }\end{array}$} & \multirow{2}{*}{$\begin{array}{l}2.1 \text { System } \\
\text { Thinking }\end{array}$} & $\begin{array}{l}\text { 2.1.1 Thinking } \\
\text { Holistically }\end{array}$ & $\begin{array}{l}\text { Identify and define a system, its behavior, Identify the } \\
\text { interactions external to the system, and the } \\
\text { behavioral impact of the system }\end{array}$ \\
\hline & & $\begin{array}{l}\text { 2.1.2 Emergence and } \\
\text { Interactions in Systems }\end{array}$ & $\begin{array}{l}\text { Identify the behavioral and functional properties } \\
\text { (intended } \\
\text { and unintended) which emerge from the system }\end{array}$ \\
\hline $\begin{array}{l}3 \text { Personal and } \\
\text { Professional } \\
\text { Skills }\end{array}$ & $\begin{array}{l}\text { 3.1 Engineering } \\
\text { Reasoning and } \\
\text { Problem Solving }\end{array}$ & $\begin{array}{l}\text { 3.1.1 Problem } \\
\text { Identification and } \\
\text { Formulation }\end{array}$ & $\begin{array}{l}\text { Grasp the overall goal, prioritize matters and formulate } \\
\text { solutions }\end{array}$ \\
\hline
\end{tabular}




\begin{tabular}{|c|c|c|c|}
\hline & & $\begin{array}{l}\text { 3.1.5 Solution and } \\
\text { Recommendation }\end{array}$ & Synthesize problem solutions \\
\hline & $\begin{array}{l}3.2 \\
\text { Experimentation } \\
\text { and Knowledge } \\
\text { Discovery }\end{array}$ & $\begin{array}{l}\text { 3.2.2 Survey of Print and } \\
\text { Electronic Literature }\end{array}$ & $\begin{array}{l}\text { Choose the literature research strategy } \\
\text { Demonstrate information search and identification using } \\
\text { library tools (on-line catalogs, databases, search engines) }\end{array}$ \\
\hline $\begin{array}{c}4 \\
\text { Communicatio } \\
n \text { and } \\
\text { Teamwork }\end{array}$ & 4.3 Teamwork & 4.3.2 Team Operation & $\begin{array}{l}\text { Practice effective communication (active listening, } \\
\text { collaboration, providing and obtaining information) }\end{array}$ \\
\hline $\begin{array}{c}7 \text { Ethical } \\
\text { Values } \\
\end{array}$ & $\begin{array}{c}7.2 \text { Professional } \\
\text { values }\end{array}$ & $\begin{array}{l}\text { 7.2.3 Individual and } \\
\text { Team Growing Together }\end{array}$ & $\begin{array}{l}\text { Team and Personal Relations Processing in Project } \\
\text { Development }\end{array}$ \\
\hline \multirow{5}{*}{$\begin{array}{l}8 \text { Social Value } \\
\text { Created by } \\
\text { Application } \\
\text { Practice }\end{array}$} & $\begin{array}{l}8.5 \text { Enterprise } \\
\text { and Business } \\
\text { Context }\end{array}$ & $\begin{array}{l}\text { 8.5.1 Basic Industry } \\
\text { Norms }\end{array}$ & $\begin{array}{l}\text { Codes, charts and documents conform to software } \\
\text { engineering specifications }\end{array}$ \\
\hline & $\begin{array}{c}\text { 8.6 Conceiving } \\
\text { and Engineering } \\
\text { Systems } \\
\end{array}$ & $\begin{array}{c}8.6 .2 \text { Defining } \\
\text { Function, Concept and } \\
\text { Architecture } \\
\end{array}$ & $\begin{array}{l}\text { Identify necessary system functions (and behavioral } \\
\text { specifications) }\end{array}$ \\
\hline & 8.7 Designing & 8.7.1 The Design Process & Synthesize the final design \\
\hline & \multirow{2}{*}{$\begin{array}{c}8.8 \\
\text { Implementing }\end{array}$} & $\begin{array}{l}\text { 8.8.3 Software } \\
\text { Implementing Process } \\
\text { Explain } \\
\end{array}$ & Designing the Implementation Process \\
\hline & & $\begin{array}{l}\text { 8.8.5 Test, Verification, } \\
\text { Validation, and } \\
\text { Certification }\end{array}$ & Discuss test and analysis procedures \\
\hline \multicolumn{3}{|c|}{$\begin{array}{l}\text { The above indicators are the T-C competence indicators that } \\
\text { need to be developed in the course of Web Application } \\
\text { Development. However, how to cultivate them in the course, } \\
\text { it needs to be refined into each unit of the course. To this end, }\end{array}$} & $\begin{array}{l}\text { we have designed mapping from curriculum competence } \\
\text { indicators to curriculum knowledge units and project units, } \\
\text { thus taking a practical step for the cultivation of these } \\
\text { competence indicators as follows: }\end{array}$ \\
\hline
\end{tabular}

\begin{tabular}{|c|c|c|c|c|c|c|c|c|c|c|c|c|c|c|c|}
\hline \multirow{3}{*}{$\begin{array}{c}\text { TOPCARES } \\
\text { (Capability } \\
\text { Indicators Level } \\
\text { 3) }\end{array}$} & \multicolumn{6}{|c|}{ Course Unit（Knowledge Unit） CU } & \multicolumn{9}{|c|}{ Unit Project(UP) and Course Project(CP) } \\
\hline & CU(1) & $\mathbf{C U}(\mathbf{2})$ & $\mathbf{C U}(3)$ & CU(4) & $\mathbf{C U}(\mathbf{5})$ & $\mathbf{C U}(6)$ & $\mathbf{U P}(\mathbf{2})$ & $\mathbf{U P}(\mathbf{2})$ & $\mathbf{U P}(2)$ & $\mathbf{U P}(3)$ & UP(6) & \begin{tabular}{|c|}
$\mathbf{U P}(\mathbf{1} /$ \\
$\mathbf{3})$ \\
\end{tabular} & \begin{tabular}{|c|}
$\mathbf{U P}(\mathbf{1} /$ \\
$\mathbf{3 / 5})$ \\
\end{tabular} & \begin{tabular}{|l|}
$\mathbf{U P}(\mathbf{1} / \mathbf{2}$ \\
$\mathbf{3 / 4 / 5})$ \\
\end{tabular} & CP(1) \\
\hline & \begin{tabular}{|c|} 
Course \\
Introduct \\
ion
\end{tabular} & $\begin{array}{l}\text { Web } \\
\text { Pages }\end{array}$ & JSP & $\begin{array}{c}\text { Database } \\
\text { Design }\end{array}$ & Servelt & Filter & $\begin{array}{c}\text { Home } \\
\text { Page } \\
\text { Design }\end{array}$ & $\begin{array}{c}\text { Informati } \\
\text { Table }\end{array}$ & $\begin{array}{c}\text { web } \\
\text { calculato } \\
\mathrm{r}\end{array}$ & \begin{tabular}{|c} 
News \\
Class \\
Design
\end{tabular} & $\begin{array}{c}\text { Authority } \\
\text { Manage } \\
\text { ment }\end{array}$ & $\begin{array}{l}\text { Internet } \\
\text { Chat } \\
\text { Room }\end{array}$ & \begin{tabular}{|l|} 
Verificati \\
on code \\
program
\end{tabular} & \begin{tabular}{|c|} 
News \\
Release \\
System \\
\end{tabular} & $\begin{array}{c}\text { Online } \\
\text { Bookstor } \\
\mathrm{e}\end{array}$ \\
\hline $\begin{array}{l}\text { 1.3.1 Professional } \\
\text { Knowledge }\end{array}$ & M & E & $\mathrm{E}$ & $\mathrm{E}$ & $\mathrm{E}$ & $\mathrm{E}$ & $\mathrm{E}$ & $\mathrm{E}$ & E & E & E & $\mathrm{E}$ & $\mathrm{E}$ & E & $\mathrm{E}$ \\
\hline \begin{tabular}{|l} 
2.1.1 Thinking \\
Holistically \\
\end{tabular} & $\mathrm{L}$ & M & M & M & $\mathrm{L}$ & $\mathrm{L}$ & M & M & M & M & M & M & M & M & M \\
\hline $\begin{array}{l}2.1 .2 \text { Emergence and } \\
\text { Interactions in Systems }\end{array}$ & $\mathrm{L}$ & E & $\mathrm{L}$ & E & $\mathrm{L}$ & $\mathrm{L}$ & M & M & M & $\mathrm{L}$ & M & M & M & M & $\mathrm{L}$ \\
\hline $\begin{array}{l}\text { 3.1.1 Problem } \\
\text { Identification and } \\
\text { Formulation }\end{array}$ & $\mathrm{L}$ & $\mathrm{L}$ & M & M & $\mathrm{L}$ & $\mathrm{L}$ & M & M & M & M & M & M & M & M & E \\
\hline $\begin{array}{l}\text { 3.1.5 Solution and } \\
\text { Recommendation }\end{array}$ & $\mathrm{L}$ & M & $\mathrm{E}$ & E & $\mathrm{E}$ & M & E & E & $\mathrm{E}$ & E & E & E & E & E & E \\
\hline $\begin{array}{l}\text { 3.2.2 Survey of Print and } \\
\text { Electronic Literature }\end{array}$ & $\mathrm{L}$ & $\mathrm{L}$ & $\mathrm{L}$ & $\mathrm{L}$ & $\mathrm{L}$ & $\mathrm{L}$ & M & M & M & M & M & M & M & M & M \\
\hline 4.3.2 Team Operation & $\mathrm{L}$ & M & M & M & M & M & $\mathrm{L}$ & $\mathrm{L}$ & $\mathrm{L}$ & $\mathrm{L}$ & $\mathrm{L}$ & $\mathrm{L}$ & $\mathrm{L}$ & M & M \\
\hline $\begin{array}{c}7.2 .3 \text { Individual and } \\
\text { Team Growing Together }\end{array}$ & $\mathrm{L}$ & E & M & E & M & M & M & M & M & M & M & M & M & M & M \\
\hline $\begin{array}{c}\begin{array}{c}8.1 \\
\text { Basic Industry } \\
\text { Norms }\end{array} \\
\end{array}$ & $\mathrm{L}$ & E & M & E & M & M & M & M & M & M & M & M & M & M & $\mathrm{E}$ \\
\hline $\begin{array}{l}8.6 .2 \text { Defining Function, } \\
\text { Concept and } \\
\text { Architecture } \\
\end{array}$ & $\mathrm{L}$ & E & $\mathrm{L}$ & E & $\mathrm{L}$ & $\mathrm{L}$ & M & M & M & M & M & M & M & M & M \\
\hline $\begin{array}{c}\text { 8.7.1 The Design } \\
\text { Process }\end{array}$ & $\mathrm{L}$ & M & $\mathrm{L}$ & $\mathrm{M}$ & $\mathrm{L}$ & $\mathrm{L}$ & $\mathrm{M}$ & $\mathrm{M}$ & $\mathrm{M}$ & $\mathrm{M}$ & $\mathrm{M}$ & $\mathrm{M}$ & $\mathrm{M}$ & $\mathrm{M}$ & $\mathrm{M}$ \\
\hline \begin{tabular}{|c|} 
8.8.3 Software \\
Implementing Process \\
Explain \\
\end{tabular} & $\mathrm{L}$ & E & $\mathrm{L}$ & E & $\mathrm{L}$ & $\mathrm{L}$ & E & E & E & E & E & E & E & E & E \\
\hline $\begin{array}{l}8.8 .5 \text { Test, Verification, } \\
\text { Validation, and } \\
\text { Certification } \\
\end{array}$ & $\mathrm{L}$ & $\mathrm{L}$ & $\mathrm{L}$ & $\mathrm{L}$ & $\mathrm{L}$ & $\mathrm{L}$ & $\mathrm{L}$ & $\mathrm{L}$ & $\mathrm{L}$ & $\mathrm{L}$ & $\mathrm{L}$ & $\mathrm{L}$ & $\mathrm{L}$ & $\mathrm{L}$ & $\mathrm{M}$ \\
\hline
\end{tabular}

Figure 1 Mapping of Training Objectives and Course Contents of Web Application Development 
In the table above, L, M and $\mathrm{E}$ denote Less, Medium and Extreme respectively, meaning the importance of the index, which comes from the research of industry enterprises and the comprehensive consideration of the curriculum system in the major talent training program. For example, it will train students' abilities of the index 2.1.2 Emergency and Interactions in Systems to the greatest extent in Unit 2 Webpages. So we mark this cell as E to show it Extremely importance, while it only can be marked as L which means Less in Unit Project 3 News Class Design, since it doesn't play a very important role in the cultivation of this competence. As for which competences need to be emphatically cultivated in which units, careful design and reasonable layout are needed. In the actual teaching process, different degrees of importance will be given different time weights. Teachers can make appropriate adjustments according to their needs, but not too fine, just need to grasp the contribution of different knowledge units to the training of different competence indicators in mind.

\section{TEACHING PROCESS AND METHOD DESIGN}

With the mapping of curriculum training objectives and curriculum content, we can clearly see which unit or units a certain index should be cultivated in and how far it should be cultivated. In the course of Web Application Development, we have designed 6 knowledge units, 8 unit projects and a comprehensive curriculum project to support the cultivation of these T-C competence indicators. However, how to cultivate, we also need to design appropriate teaching methods, combined with different teaching modes, as well as specific activities to achieve the goal. Therefore, according to the characteristics of curriculum unit knowledge, we have selected two main teaching methods, five teaching modes, and combined with a number of different activity designs to complete the training of $\mathrm{T}-\mathrm{C}$ competence indicators, as shown in the following Figure:

\begin{tabular}{|c|c|c|c|c|c|c|c|c|c|c|c|c|c|c|c|c|}
\hline Week & 1 & 2 & 3 & 4 & 5 & 6 & 7 & 8 & 9 & 10 & 11 & 12 & 13 & 14 & 15 & 16 \\
\hline $\begin{array}{l}\text { Course } \\
\text { Stage } \\
\end{array}$ & \multicolumn{2}{|c|}{ Course Introduction } & \multicolumn{2}{|c|}{$\begin{array}{c}\text { Requirement } \\
\text { Analysis }\end{array}$} & \multicolumn{4}{|c|}{ System Design } & \multicolumn{5}{|c|}{ System Implementation } & \multicolumn{3}{|c|}{$\begin{array}{c}\text { System Integration, Testing } \\
\text { and Operation }\end{array}$} \\
\hline $\begin{array}{l}\text { Teaching } \\
\text { Method }\end{array}$ & \multicolumn{16}{|c|}{ Project-based and Problem-based Teaching Method } \\
\hline \multirow{2}{*}{$\begin{array}{c}\text { Delivery } \\
\text { Mode }\end{array}$} & \multicolumn{4}{|c|}{ On-line Self-Study } & \multicolumn{4}{|c|}{ Discussion Teaching Method } & \multicolumn{8}{|c|}{ Group Learning } \\
\hline & \multicolumn{5}{|c|}{ Flipped Classroom } & \multicolumn{11}{|c|}{ Role-playing and Case-based Teaching Method } \\
\hline $\begin{array}{c}\text { Teaching } \\
\text { Activities } \\
\text { Design }\end{array}$ & $\begin{array}{l}\text { Throw out } \\
\text { tasks and } \\
\text { problems, } \\
\text { and learn } \\
\text { online }\end{array}$ & $\begin{array}{l}\text { Personal } \\
\text { discussion, } \\
\text { exchange } \\
\text { opinions, } \\
\text { and set up } \\
\text { developmen } \\
\text { t team. }\end{array}$ & \begin{tabular}{|l|} 
Teacher \\
gives lecture \\
(summarizin \\
$\mathrm{g}$ \\
students'opi \\
nions and \\
introducing \\
new \\
knowledge)
\end{tabular} & $\begin{array}{l}\text { Further } \\
\text { access to } \\
\text { online } \\
\text { information } \\
\text { to identify } \\
\text { system } \\
\text { needs. }\end{array}$ & \begin{tabular}{|l|} 
Web \\
Developme \\
nt Project \\
Design \\
Group \\
Discussion
\end{tabular} & \begin{tabular}{|l} 
Students \\
collect and \\
share design \\
information.
\end{tabular} & $\begin{array}{l}\text { Debate in } \\
\text { groups to } \\
\text { determine } \\
\text { the design } \\
\text { plan. }\end{array}$ & $\begin{array}{l}\text { Teachers } \\
\text { evaluate } \\
\text { each group } \\
\text { and give } \\
\text { suggestions. }\end{array}$ & \begin{tabular}{|l} 
Team task \\
division, \\
database \\
implementati \\
on.
\end{tabular} & $\begin{array}{l}\text { Teacher } \\
\text { case } \\
\text { guidance. }\end{array}$ & $\begin{array}{l}\text { Background } \\
\text { Function } \\
\text { Realization }\end{array}$ & $\begin{array}{l}\text { Teacher } \\
\text { Case } \\
\text { Guidance。 }\end{array}$ & $\begin{array}{l}\text { Front-end } \\
\text { interface } \\
\text { implementati } \\
\text { on. }\end{array}$ & $\begin{array}{l}\text { Project } \\
\text { Integration } \\
\text { and } \\
\text { Debugging }\end{array}$ & $\begin{array}{l}\text { Project } \\
\text { testing and } \\
\text { operation }\end{array}$ & $\begin{array}{l}\text { Project } \\
\text { demonstrati } \\
\text { on and } \\
\text { defense }\end{array}$ \\
\hline $\begin{array}{c}\text { Correspon } \\
\text { ding T-C } \\
\text { Index }\end{array}$ & $\begin{array}{l}1.3 .1 \\
3.2 .2\end{array}$ & 3.1 .1 & 1.3 .1 & $\begin{array}{l}3.2 .2 \\
8.5 .1\end{array}$ & $\begin{array}{l}3.1 .1 \\
4.3 .2 \\
7.2 .3\end{array}$ & $\begin{array}{l}3.2 .2 \\
8.6 .2\end{array}$ & $\begin{array}{l}2.1 .1 \\
4.3 .2 \\
7.2 .3 \\
8.7 .1\end{array}$ & 3.1 .5 & 4.3 .2 & 3.1 .5 & $\begin{array}{l}4.3 .2 \\
8.8 .3\end{array}$ & 3.1 .5 & $\begin{array}{l}2.1 .2 \\
4.3 .2 \\
8.8 .3\end{array}$ & 8.8 .5 & 8.8 .5 & 7.2 .3 \\
\hline
\end{tabular}

Figure 2 Teaching Method and Process Design- Web Application Development

The figure above shows the teaching methods and modes to be adopted at different stages of the teaching process in the form of time axis, as well as the competence indicators to be cultivated. For example, in the fourth week of the implementation of the curriculum, we mainly carry out the system requirement analysis, using the combination of students' autonomous learning and flipping classroom to complete the training of indicators 3.2.2 and 8.5.1. In the thirteenth week, the group learning method combined with role-playing and case-based teaching method was used to develop the system, so as to achieve the training of indicators 2.1.2, 4.3.2 and 8.8.3. The whole 16-week course learning is based on project-based $\mathrm{t}$ and problem-based teaching these two main methods. Different competence indicators have matching teaching methods and modes to cultivate in the appropriate time, which requires teachers to have a very rich teaching experience and a profound understanding of the indicators, in order to achieve perfect coordination between them.

\section{COURSE ASSESSMENT}

Since the curriculum is designed and implemented around $\mathrm{T}-\mathrm{C}$ competence indicators, so the traditional written examination method is far from enough in the assessment process, but should be based on different competence indicators, combined with a variety of assessment methods, to conduct an all-round full coverage of the assessment. In the course of Web Application Development, we have designed two evaluation stages and five different evaluation methods to evaluate students' performance comprehensively. Each evaluation method has a different proportion, and corresponds to each T-C capability index, as shown in the following table: 
Table 2 T-C Index And Assessment Mapping

\begin{tabular}{|c|c|c|c|c|c|c|c|c|c|c|c|c|c|c|c|}
\hline \multirow{2}{*}{$\begin{array}{l}\text { Assessment } \\
\text { Methods }\end{array}$} & \multirow{2}{*}{$\begin{array}{c}\text { Formativ } \\
\text { e } \\
\text { assessme } \\
\text { nt } \\
\end{array}$} & \multirow{2}{*}{$\begin{array}{c}\text { Final } \\
\text { Assess } \\
\text { ment }\end{array}$} & \multicolumn{13}{|c|}{ T-C Index Level 3} \\
\hline & & & $\begin{array}{c}1.3 . \\
1\end{array}$ & $\begin{array}{c}2.1 . \\
1\end{array}$ & $\begin{array}{c}2.1 . \\
2\end{array}$ & $\begin{array}{c}3.1 . \\
1\end{array}$ & $\begin{array}{c}3.1 . \\
5\end{array}$ & $\begin{array}{c}\text { 3.1. } \\
2\end{array}$ & $\begin{array}{c}4.3 . \\
2 \\
\end{array}$ & $\begin{array}{c}7.2 . \\
3\end{array}$ & $\begin{array}{c}8.5 . \\
1 \\
\end{array}$ & $\begin{array}{c}\text { 8.6. } \\
2\end{array}$ & $\begin{array}{c}8.7 . \\
1\end{array}$ & $\begin{array}{c}8.8 . \\
3 \\
\end{array}$ & $\begin{array}{c}8.8 . \\
5\end{array}$ \\
\hline $\begin{array}{l}\text { Course } \\
\text { Project and } \\
\text { Respondents }\end{array}$ & $30 \%$ & & $\sqrt{ }$ & $\sqrt{ }$ & $\sqrt{ }$ & $\sqrt{ }$ & $\sqrt{ }$ & $\sqrt{ }$ & $\sqrt{ }$ & $\checkmark$ & $\sqrt{ }$ & $\sqrt{ }$ & $\sqrt{ }$ & $\sqrt{ }$ & $\sqrt{ }$ \\
\hline $\begin{array}{l}\text { Homework } \\
\text { and } \\
\text { Classroom } \\
\text { Performance }\end{array}$ & $9 \%$ & & $\sqrt{ }$ & & & $\sqrt{ }$ & $\sqrt{ }$ & $\sqrt{ }$ & $\sqrt{ }$ & & & & $\sqrt{ }$ & & \\
\hline Attendance & $6 \%$ & & & & & & & & $\sqrt{ }$ & $\sqrt{ }$ & & & & & \\
\hline Experiments & $15 \%$ & & & & $\sqrt{ }$ & $\checkmark$ & $\checkmark$ & $\sqrt{ }$ & & & & & $\sqrt{ }$ & & \\
\hline $\begin{array}{l}\text { Final } \\
\text { Closed-book } \\
\text { Examination }\end{array}$ & & $40 \%$ & $\sqrt{ }$ & & & & & & & & $\sqrt{ }$ & $\sqrt{ }$ & & & \\
\hline $\begin{array}{l}\text { Total } \\
\text { Score }(100 \% \\
\text { ) }\end{array}$ & $60 \%$ & $40 \%$ & & & & & & & & & & & & & \\
\hline
\end{tabular}

Course assessment only generally reflects the competency indicators mainly be evaluated by which assessment methods, but does not refine the specific scores of each competency indicators. If we need to reflect the degree of achievement of each index, we need to do further detailed assessment programs, assign different weights to different indicators, which is also the focus of our next research.

\section{CONCLUSIONS}

The method of curriculum design and assessment based on $\mathrm{T}-\mathrm{C}$ proposed in this paper has been applied to various courses in our college and achieved good results. The difficulties in curriculum design lie in the selection of T-C indicators, the design of teaching activities and the assessment of indicators. Among them, in the determination of T-C indicators, a large number of major research and overall consideration of the curriculum architecture are needed to select a more reasonable curriculum T-C indicators. Teaching activities should be designed according to different $\mathrm{T}-\mathrm{C}$ indicators, which requires teachers to have rich teaching experience and a profound understanding of the indicators. For the assessment of T-C indicators, a balance between accuracy and ambiguity is needed in order to achieve the accuracy and efficiency of the assessment of indicators.

\section{ACKNOWLEDGMENT}

This work was supported by the National Institute of Computer Basic Education in Colleges and Universities under Grant No. 2018-AFCEC-190, and the Higher Education Talents Training Quality and Teaching Reform Projects of Sichuan Province in 2018-2020 under Grant No.JG2018-901.

\section{REFERENCES}

[1] Svensson, Tomas,Gunnarsson, Svante. " $A$ Design-Build-Test course in electronics based on the CDIO framework for engineering education"[J]. International Journal of Electrical Engineering Education,2012,49(4). 2019.

[2] Wang, Yanru,Zheng, Shuqin,Zhang, Maoyu,Li, Bo. "Mode Reform of Sensor Courses Teaching in Civil Engineering Based on CDIO Education Concept"[J]. Sensors \& Transducers, 2014,173(6).

[3] E A Boiko,P V Shishmarev,D I Karabarin,S R Yanov,A A Pikalova. "Implementing CDIO project-based learning in training of Heat and Power engineers" [J]. Journal of Physics: Conference Series,2017,891(1). [4]xxxx

[4] Ming Luo,Lei Shi,Ming-Jing Xie. "Research on the construction performance assessment of industry-university-research cooperation in collaborative innovation to promote the practice base construction based on CDIO idea" $[\mathrm{J}]$. Journal of Intelligent \& Fuzzy Systems,2017,33(6).

[5] Daneykin Yury,Daneikina Natalia,Sadchenko Viktoria. "Implementation of CDIO Approach in training engineering specialists for the benefit of sustainable development" [J]. MATEC Web of Conferences,2016,48. 